\title{
Rodent Models of Non-classical Progesterone Action Regulating Ovulation
}

\section{OPEN ACCESS}

Edited by:

Shyama Majumdar, University of Illinois at Chicago,

United States

Reviewed by:

Andrew Wolfe,

Johns Hopkins University,

United States

Ignacio Camacho-Arroyo, National Autonomous University

of Mexico, Mexico

${ }^{*}$ Correspondence:

Melinda A. Mittelman-Smith melindasmith@mednet.ucla.edu

Specialty section: This article was submitted to Cellular Endocrinology, a section of the journal Frontiers in Endocrinology

Received: 01 March 2017 Accepted: 27 June 2017

Published: 24 July 2017

Citation: Mittelman-Smith MA, Rudolph LM, Mohr MA and Micevych PE (2017)

Rodent Models of Non-classical Progesterone Action Regulating Ovulation.

Front. Endocrinol. 8:165. doi: 10.3389/fendo.2017.00165
Melinda A. Mittelman-Smith*, Lauren M. Rudolph, Margaret A. Mohr and Paul E. Micevych

Department of Neurobiology, David Geffen School of Medicine at UCLA, The Laboratory of Neuroendocrinology, Brain Research Institute, University of California Los Angeles, Los Angeles, CA, United States

It is becoming clear that steroid hormones act not only by binding to nuclear receptors that associate with specific response elements in the nucleus but also by binding to receptors on the cell membrane. In this newly discovered manner, steroid hormones can initiate intracellular signaling cascades which elicit rapid effects such as release of internal calcium stores and activation of kinases. We have learned much about the translocation and signaling of steroid hormone receptors from investigations into estrogen receptor $\alpha$, which can be trafficked to, and signal from, the cell membrane. It is now clear that progesterone (P4) can also elicit effects that cannot be exclusively explained by transcriptional changes. Similar to E2 and its receptors, P4 can initiate signaling at the cell membrane, both through progesterone receptor and via a host of newly discovered membrane receptors (e.g., membrane progesterone receptors, progesterone receptor membrane components). This review discusses the parallels between neurotransmitterlike E2 action and the more recently investigated non-classical P4 signaling, in the context of reproductive behaviors in the rodent.

Keywords: estrogen, progesterone, reproduction, lordosis, ovulation, luteinizing hormone, hypothalamus, kisspeptin

\section{INTRODUCTION}

For years, we understood that steroids functioned as ligand-gated transcription factors that enacted changes in gene expression (1). This classic dogma of steroid hormones operating exclusively through nuclear response elements to modify gene transcription has been challenged and expanded. While many processes do rely on this "classical" mode of steroid hormone signaling, our understanding of how steroid hormones signal has developed dramatically, including a recent argument for steroid classification as neurotransmitters $(2,3)$. Much of this recent understanding of how steroids signal was developed from studies about estrogen (E2) signaling, but we now understand that non-classical signaling is likely to occur across all classes of steroids. This review briefly highlights initial discoveries of the molecular methods of non-classical E2 signaling and focuses on more recent advances in our understanding of how progesterone (P4) signaling appears to function in a similar fashion, with membrane-initiated events involving a variety of receptors that regulate critical aspects of reproduction.

First, the nomenclature used to discuss steroid hormone action should be considered. The "nonclassical" method of steroid action has been called rapid or sometimes non-nuclear. Importantly, caution should be exercised when generalizing these terminologies to encompass all "non-classical" 
steroid signaling. First, the term rapid is relative and does not indicate a clear temporal delineation by which effects could be categorized as non-rapid. At what time point, do steroid effects cease to be rapid? In this review, we will use the term rapid to describe effects occurring within minutes, though throughout scientific literature this term may be used more loosely. Second, while steroid effects can be mediated by non-nuclear receptors, in certain cases, it may be technically incorrect to refer to these events as non-nuclear. Activation of membrane-localized receptors can (and often do) ultimately lead to activation of nuclear response elements and transcriptional changes [e.g., via activation of CREB $(4,5)]$. Therefore, it is more accurate to use terms such as non-classical or membrane-initiated signaling to encompass all signaling arising from steroid hormone activation of membrane-bound receptors. This inclusive terminology is appropriate for non-classical steroid signaling of all varieties, as it describes not only initiation of rapid second messenger pathways but also effects arising from the membrane and culminating in transcriptional and translational changes.

Over the past several decades, E2-activated non-classical signaling cascades have been elucidated by research groups, including our own, who were largely focused on the mechanisms of E2 signaling [reviewed in Ref. (6-11)]. Relatively little is known about membrane-initiated effects of P4 (particularly in the CNS), but there are striking similarities between non-classical E2 and P4 signaling, suggesting a commonality of mechanisms. This review will discuss the hallmarks of non-classical E2 signaling alongside the growing literature of membrane-initiated P4 signaling, and how neurotransmitter-like effects of these steroid hormones function, often interdependently, to direct the structure and function of neuroendocrine systems critical for reproduction.

\section{NON-CLASSICAL STEROID SIGNALING}

While the critical role of steroid hormones in reproduction is well established, new lines of research are demonstrating that the formerly termed "gonadal hormones" are also synthesized and act at extra-gonadal regions [reviewed in Ref. $(3,12,13)$ ]. Nonclassical steroid signaling has been most thoroughly studied with E2; however, as novel mechanisms of steroid signaling continue to be the target of investigation, it appears that most (and perhaps all) steroid hormones can and do function as E2 does, in both classical and non-classical ways. To demonstrate the parallels between the known aspect of non-classical E2 signaling and the developing literature of neurotransmitter-like P4 signaling, this review is structured to address the aspects of $\mathrm{P} 4$ signaling that are known to replicate the mechanisms of neurotransmitter-like E2 signaling. Therefore, we focus on rapid, membrane-initiated effects of P4, neural synthesis of P4, and the wide array of $\mathrm{P} 4$-binding proteins and their trafficking, all in the greater context of the classical reproductive events of the female rodent: lordosis and the luteinizing hormone (LH) surge triggering ovulation.

\section{Rapid, Membrane-Initiated Effects Estradiol}

Hypothalamic circuits are essential regulators of negative and positive feedback loops that govern reproductive functions.
These circuits are exquisitely sensitive to and regulated by steroid hormones. While this review focuses on the mechanisms of P4-mediated signaling in reproduction, it is important to consider the interaction of $\mathrm{P} 4$ and E2 signaling pathways and how these steroid hormones act to co-regulate reproductive events in animals, and specifically in female rodents.

Initial evidence indicating non-genomic actions of E2 has been known for decades, as effects could be elicited on a time course too short to allow for transcription and translation to occur (14). Most research during this time assessed steroid hormone effects hours or days after hormone treatment, precluding the possibility of discovering rapid effects and further solidifying the idea that steroid hormones acted to regulate transcription. Since then, examination of additional experimental time points and new methodologies have allowed for the assessment of rapid effects of E2 and P4 on neural structure, function, and behaviors. With a short exposure to E2, mu-opioid receptors are activated and internalized, a step critical for the subsequent, delayed expression of sexual receptivity (15). This effect can be elicited within minutes by cell-impermeable E-6-BSA (E2 conjugated to bovine serum albumin), demonstrating that these E2 actions are both rapid and membrane-initiated (16). In vitro, membrane-initiated E2 signaling elicits changes in gene expression (17), demonstrating that E2 action at the membrane does not preclude changes in gene expression, and can initiate genomic changes. Indeed, our own in vitro experiments have demonstrated mRNA and protein changes occurring 24-48 h after E-6-BSA treatment (18). In vivo, membrane-initiated E2 signaling can augment the effects of "classical" E2 signaling, the latter involving genomic mechanisms (19). This non-classical E2 signaling at the membrane occurs via estrogen receptor $\alpha(\mathrm{ER} \alpha)$ coupled to the metabotropic glutamate receptor 1a (mGluRla) at the cell membrane, initiating second messenger intracellular signaling cascades $(5,20)$. Further highlighting the interaction of non-classical and classical steroid signaling, $\mathrm{ER} \alpha$ signaling at the membrane is secondary to the trafficking of "classical" ER $\alpha$ to the cell surface. Here, ER $\alpha$ associates with caveolin molecules that are necessary for membrane-initiated E2 signaling via mGluR1a (21). Palmitoylation sequences in the $\mathrm{ER} \alpha$ gene provide a substrate for association with caveolin-1 (22), which mediates trafficking to the cell membrane and mGluR-associated signaling (23). Therefore, both membraneinitiated and classical genomic E2 signaling is mediated by $\mathrm{ER} \alpha$, and it is its cellular localization that determines which mechanism of signaling is activated. It is possible, but not yet elucidated whether $\mathrm{P} 4$ acts like E2, using the same receptor to mediate both classical and membrane-initiated effects via trafficking of the receptor.

\section{Progesterone}

Accumulating evidence suggests that P4, similar to E2, can signal through non-classical mechanism(s): P4 or membranerestricted P4 (P4-3-BSA) affects cellular signaling in seconds to minutes, suggesting a plasma membrane-initiated action. In the CNS, rapid actions of $\mathrm{P} 4$ have been shown to alter neuronal responsivity in various cell types and affect a variety of physiological processes, including neuroprotection and reproduction 
(24-30). For example, in ovariectomized (ovx) rats, within 5-15 min after P4 administration, responses to glutamate decrease, and inhibitory responses to GABA increase (25). Relevant to reproduction, $\mathrm{P} 4$ upregulates oxytocin receptor binding and lordosis behavior within $30 \mathrm{~min}$ of administration (24). Rapid effects of P4 also modulate reproduction-related neurotransmitter release that can alter sexual receptivity, such as dopamine and acetylcholine (31), as well as norepinephrinestimulated cyclic AMP (cAMP) $(32,33)$. P4 membrane signaling has been associated with gonadotropin-releasing hormone $(\mathrm{GnRH})$ release, although the exact role of $\mathrm{P} 4$ in $\mathrm{GnRH}$ release is unresolved $(29,34)$. Using a superfusion technique, P4-3BSA stimulates $\mathrm{GnRH}$ release, demonstrating that P4-induced $\mathrm{GnRH}$ release is initiated at the plasma membrane (34). Given that $\mathrm{P} 4$ regulates neuroendocrine events that occur on both acute and more protracted time scales, it follows that the effects of $\mathrm{P} 4$ could be mediated through both classical and non-classical signaling mechanisms. A growing body of literature indicates that $\mathrm{P} 4$ metabolites can also function in various physiological pathways having anti-anxiety, anesthetic, and neuroprotective properties [e.g., Ref. (35-37)]. However, whether these metabolites signal through classical or non-classical receptors or whether their signaling is membrane-initiated or nuclear is not yet known.

\section{Non-Classical Receptor Signaling}

Originally, there was only one known estrogen receptor, "ER" (now called $\operatorname{ER} \alpha$ ). Since the subsequent discovery of $\operatorname{ER} \beta$, there is an ever increasing number of estrogen-binding proteins that have been discovered. In addition to $E R \alpha$ and $E R \beta$, there has been a growing literature on mechanisms of E2 mediated via non-classical receptors, such as the $\mathrm{G}$ protein-coupled estrogen receptor 1, GPER (originally GPR30). Other estrogen receptors, putative and known, including ER-X and STX, remain the targets of many lines of research in the non-classical E2 signaling field. The continual discovery of novel receptors suggests that P4 signaling will also involve a variety of P4-binding proteins through which non-classical P4 action occurs.

\section{“Classical” Progesterone Receptor (PGR) on the Membrane}

Similar to E2 signaling, we now understand that not only does P4 signaling involve novel receptors but also that classical receptors can function in novel ways (e.g., at the membrane). The "classical" PGR has many structural properties similar to $\mathrm{ER} \alpha$ that could allow membrane trafficking (38). For example, PGR contains a 9 amino acid motif that mediates palmitoylation-induced membrane translocation (38). This palmitoylation sequence facilitates association of mGluRs with ERs and appears to be conserved across multiple steroid hormone receptors, including PGR. Therefore, P4 could act as E2 does at the membrane, via palmitoylation-induced trafficking and association with mGluRs. However, whether there is a PGR-mGluR association has not been examined to date. Though not discussed in this review, there is also evidence that PGR can be activated in a "ligand-independent" manner by neurotransmitters and other factors to affect various processes and behaviors critical to reproduction [reviewed in Ref. (39, 40)]. In addition to PGR, other, non-classical P4-binding proteins have been more recently discovered that may contribute to reproductive processes (see Figure 1).

\section{Membrane Progesterone Receptors (mPRs)}

The wealth of data suggests that classical PGR is critical for P4 facilitation of the LH surge, but LH release can be affected in PGR knockout (PRKO) animals, suggesting the possibility that P4 signals through non-classical PGRs to affect LH release (29). While the specific roles of non-classical PGRs in LH release are unknown, their neuroanatomical locations and their functions in non-neural reproductive tissues supports the idea that these receptors can mediate rapid, membrane-initiated $\mathrm{P} 4$ signaling. Two different types of non-classical receptor families mediate membrane-initiated actions of $\mathrm{P} 4$ : the 7 transmembrane domain membrane $\mathrm{P} 4$ receptors ( $\mathrm{mPRs}$ ) that belong to the Class II progestin and adipoQ receptor (PAQR) family $(45,46)$ and the membrane-associated PGR family including progesterone receptor membrane components 1 and 2 [PGRMC1 and 2 $(46,48)$; discussed below]. There are various subtypes of $\mathrm{mPR}$ : mPR $\alpha$ (PAQR7), mPR $\beta$ (PAQR8), mPR $\gamma$ (PAQR5), mPR $\delta$ (PAQR6), and mPRe (PAQR9) (49). These mPR subtypes exhibit high-affinity binding of $\mathrm{P} 4$ at the cell membrane $(49,50)$ and act somewhat like unique $G$ protein-coupled receptors (51). Some $\mathrm{mPRs}$ (including $\mathrm{mPR} \alpha, \mathrm{mPR} \beta$, and $\mathrm{mPR} \gamma$ ) can mediate rapid $\mathrm{P} 4$ actions by activation of an inhibitory $G$ protein $\left(G_{i}\right)$ and suppression of adenylyl cyclase activity and cAMP production [Figure 1; $(45,46)$ ].

Based on expression patterns and responsivity to E2, the most reproductively relevant $\mathrm{mPRs}$ appear to be $\mathrm{mPR} \alpha$ and $\mathrm{mPR} \beta . \mathrm{mPR} \alpha$ expression levels are high in the testis, ovary, and placenta (45). Expression of $\mathrm{mPR} \alpha$ is also observed, albeit at lower levels, in the CNS, including the hypothalamus $(52,53)$. Low central expression may indicate that $\mathrm{mPR} \alpha$ mediates rapid $\mathrm{P} 4$ effects more so in the periphery than in the CNS. Centrally, $\operatorname{mPR} \beta$ is the primary mPR subtype (45), with particularly high expression in reproductively relevant hypothalamic structures including the paraventricular nucleus, ventromedial hypothalamus, and arcuate nucleus, as well as forebrain structures including the medial septum and horizontal diagonal band (53). One of the first demonstrations of P4 signaling through $\mathrm{mPRs}$ showed that progestin-dependent $\mathrm{mPR} \alpha$ activation increases sperm motility and oocyte maturation in teleost fish $(45,54,55)$. While both $\mathrm{mPR} \alpha$ and $\mathrm{mPR} \beta \mathrm{mRNAs}$ are demonstrated in the hypothalamus, their physiological relevance has not been determined in the rodent. In addition to localization patterns, E2 responsivity of $\mathrm{mPR}$ subtypes is also isoform specific. E2 does not appear to affect hypothalamic levels of $\operatorname{mPR} \alpha(53)$, while on the other hand, $\operatorname{mPR} \beta$ is induced by $\mathrm{E} 2$ in the female rat hypothalamus in vivo. However, in vitro, E2 did not induce upregulation of $\mathrm{mPR} \beta$ in immortalized RP3V kisspeptin (Kiss1) neurons (41), suggesting that this upregulation may occur in cell types not directly involved in governing the LH surge (discussed below). However, local expression of $\mathrm{mPRs}$, along with $\mathrm{mPR} \beta$ induction by $\mathrm{E} 2$, indicates $\mathrm{mPRs}$ 


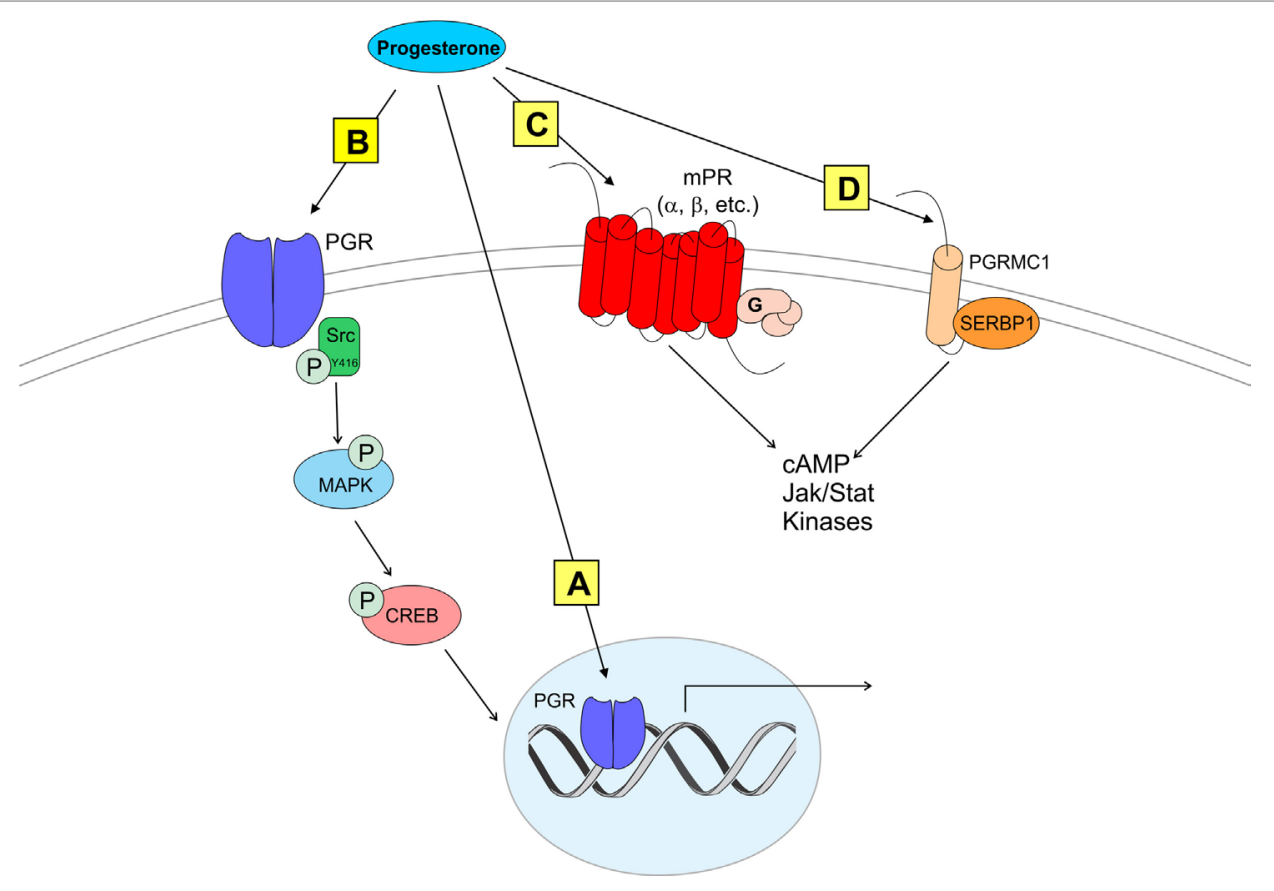

FIGURE 1 | Modes of progesterone signaling in the rodent. Classical progesterone receptor (PGR) can mediate progesterone signaling classically (A), by binding to DNA progesterone response elements. PGR can also be trafficked to the plasma membrane [as in panel (B)] where it can activate rapid intracellular signaling cascades involving kinases such as Src (41-43). It is unknown whether membrane PGR transactivates another receptor like an mGluR as estrogen receptors have been shown to do $(5,16,44)$. Multiple novel membrane progesterone receptors (mPRs) have been recently discovered and described, such as mPRs $\alpha, \beta, \delta$, and $\gamma$ (C). mPRs can activate signaling cascades via G proteins, which go on to affect cyclic AMP (cAMP) pathways (45, 46). Finally, progestins can bind to progesterone receptor membrane component 1 [PGRMC1 (D)]. PGRMC1 can work in concert with SERBP1 to affect cAMP, Jak/Stat, and multiple kinase pathways [reviewed in Ref. (47)].

could function in a facilitatory role in signaling pathways underlying the surge.

\section{Progesterone Receptor Membrane Components (PGRMCs)}

Progesterone receptor membrane components are another set of non-classical proteins that mediate $\mathrm{P} 4$ membrane-initiated signaling. PGRMCs are thought to be involved in an array of functions, including trafficking of other receptors to the membrane, cell survival, modulation of enzymes involved in steroid synthesis, steroidogenesis, and progesterone-responsiveness (48, 56-58). Most work investigating PGRMC function stems from cancer biology research and involves non-neural reproductive tissues, so the question remains whether PGRMCs play similar roles in the brain. In fact, only PGRMC1 (also known as 25-DX in the rodent) appears to bind progestins $(56,59)$ and a functional role for PGRMC2 has yet to be elucidated. However, PGRMC1 and PGRMC2 are expressed in both peripheral reproductive tissues and throughout reproductively relevant brain nuclei, particularly in the hypothalamus. Therefore, while the functionality of these receptors in reproduction is not fully understood, their expression patterns suggest they are anatomically positioned for a role in reproduction $(52,60)$.

Progesterone receptor membrane component 1 appears to function primarily through partnering with other proteins. In the ovary, PGRMC1 forms a complex with serpine mRNA-binding protein 1 (SERBP1), which is necessary for P4's antiapoptotic effect in granulosa cells $(56,61)$. In the brain, patterns of PGRMC1 and SERBP1 expression strongly overlap, further supporting the idea that these proteins partner to form a functional receptor $(52,61)$. Interestingly, the region of the brain containing the highest expression of mRNAs encoding PGRMCs and SERBP1 is the anteroventral periventricular nucleus (AVPV) (52), one of the most important neural sites for estrogen positive feedback underlying ovulation. Indeed, ovarian hormones, alone or in concert, regulate PGRMC1, SERBP1, PGRMC2, and $\mathrm{mPR} \beta$ expression in the brain $(53,62)$. PGRMC1 and SERBP1, but not mPRs, are expressed in GnRH neurons and have been implicated in P4's inhibition of $\mathrm{GnRH}$ neuronal activity through protein kinase $\mathrm{G}$ signaling (30), suggesting a possible role for PGRMC1 in terminating the LH surge. PGRMC1 may also function as an adaptor protein for multiple classes of steroid receptors, as PGRMC1 has been shown to transport $m P R \alpha$ and $\operatorname{ER} \beta$ to the cell surface in a breast cancer cell line (63), but whether PGRMC1 acts as an adaptor protein in the brain is unknown.

The PGRMC structure is different than that of $G$ proteincoupled receptors or of classical steroid hormone receptors. PGRMCs are unique in that they possess a cytochrome b5-like heme/steroid-binding domain where enzymes involved in steroid hormone synthesis can bind (64). This binding domain allows PGRMC1 to bind and enhance the activity of steroid-synthesizing P450 enzymes $(38,48)$. For example, it has been demonstrated 
that PGRMC1 binds to Cyp51A1 and is required for its activity in cholesterol synthesis (38). PGRMC1 also promotes the activity of aromatase, an enzyme crucial for estrogen synthesis (65). These interactions with P450 enzymes suggest a role for PGRMC1 in steroid synthesis, and perhaps PGRMC1 is involved in neural synthesis of steroid hormones.

\section{Neural Synthesis of Steroids}

A hallmark of "non-classical" steroid action is the understanding that steroids can be synthesized on demand, and in neural tissue. This contradicts the long-standing dogma of peripheral steroid synthesis and transport to distant target tissues was the sole mechanism of steroid hormone action. Indeed, the notion of neurosteroid production has been known for years, in rodents and in avian species [for review, see Ref. $(66,67)$ ], but we now better understand the mechanisms of how this occurs. In birds and rodents, local action of aromatase in the brain is responsible for the conversion of testosterone to E2, allowing for on-demand production of E2 (68), which has rapid, potent effects on seizure behavior (69), learning and memory (70), and reproductionrelated functions (71), in both males and females (72). Given that highly specific enzymatic activity appears to be responsible for rapid, local production of E2 in the nervous system, it is likely that P4 synthesis in the brain is regulated in a similar fashion. Indeed, it is known that $\mathrm{P} 4$ is produced from steroid precursors within specific regions and cell types of the nervous system, but the mechanisms of this process, including spatiotemporal resolution and rate-limiting step of this pathway have yet to be determined. However, given the parallels between non-classical E2 and P4 signaling, it is likely that the regulation of $\mathrm{P} 4$ production in the nervous system is governed by similar mechanisms.

\section{Neuroprogesterone}

Similar to E2, P4 is synthesized in the CNS. The synthesis of P4 within the central nervous system (neuroprogesterone or neuroP) is facilitated by E2, is sexually differentiated, and is a critical step in reproduction. NeuroP synthesis can be stimulated by $\mathrm{E} 2$ in the hypothalamus of female rodents, but not in males (73). This is mirrored physiologically, in that neuroP is critical for E2 positive feedback underlying the LH surge, which occurs in female, but not male, rodents. Originally, the adrenal gland was proposed to be the source of preovulatory $\mathrm{P} 4$ necessary for E2 positive feedback (74-77). However, removal of peripheral sources of P4 by ovx and adrenalectomy ( $\operatorname{adx})$ only blunts the E2-induced LH surge but does not eliminate it (73). In addition, peripheral levels of $\mathrm{P} 4$ peak after, not before, the LH surge (Figure 2). Importantly, when hypothalamic neuroP synthesis is blocked with a $3 \beta$-hydroxysteroid dehydrogenase $(3 \beta$-HSD) inhibitor in ovx/adx rats, the LH surge is entirely eliminated (73). Central (3V) administration of P4 in these animals restores the LH surge. Further, in gonadally intact cycling female rats, blocking conversion of pregnenolone to $\mathrm{P} 4$ with aminoglutethimide (AGT, an inhibitor of P450scc enzyme) arrests estrous cyclicity and prevents the LH surge (78-81). Together, these results demonstrate that de novo synthesis of neuroP is a critical, downstream component of E2 positive feedback underlying the LH surge (see Figure 2).
In astrocytes, neuroP synthesis is mediated by membraneinitiated E2 signaling. Here, E2 acts through a membrane ER $\alpha-m G l u R 1$ c complex, which in turn activates phospholipase $\mathrm{C}$ and inositol trisphosphate, causing a release of intracellular calcium. E2 facilitation of neuroP synthesis within hypothalamic astrocytes is regulated by protein kinase A signaling, which causes phosphorylation and activation of steroid acute regulatory protein (StAR) and translocator protein (TSPO) (82). As in other cells, activated StAR and TSPO mediate the rate-limiting step of steroidogenesis, transport of cholesterol into the mitochondrion [(83); reviewed in Ref. (84); but see Ref. (85)].

E2-induced facilitation of neuroP synthesis in vivo correlates well with the sex- and age-specific ability to mount an LH surge. E2 does not facilitate neuroP synthesis in male hypothalamic astrocytes (86) and male rats are incapable of displaying an E2- or P4-induced LH surge (87). Similarly, the development of E2 positive feedback signaling that facilitates the LH surge occurs around the same time as the development of E2-induced neuroP synthesis in females. Prior to 28 days of age, a female rat will display an LH surge only in response to supra-physiological levels of E2, and lower levels will elicit a delayed surge. It is only after 28 days of age that a female rat will mount a temporally relevant $\mathrm{LH}$ surge in response to preovulatory levels of E2 (88). Observations from our laboratory indicate that prepubertal astrocytes do not synthesize neuroP in response to E2 administration (89), and maturation of these astrocytes in vitro does not induce the ability to respond to E2. In contrast, astrocytes harvested from adult female mice respond to E2 by synthesizing neuroP (90). This divergence of E2 responsivity between prepubertal and adult female astrocytes indicates a gain of function at the level of the hypothalamic astrocyte during puberty.

One possibility is that new cells born during puberty are responsive to E2 stimulation. Indeed, new populations of hypothalamic astrocytes are born in the AVPV during puberty, coinciding with the onset of E2 positive feedback and initial LH surges [Figure 4; (91)]. The appearance of these newborn astrocytes coincides with E2 responsivity of the hypothalamus. An intriguing hypothesis is that astrocytes born during and after puberty are the source of neuroP within the hypothalamus, thereby mediating estrogen positive feedback. Further experiments are needed to determine if newly born astrocytes in the hypothalamus are the source of neuroP that is critical for the LH surge.

\section{NON-CLASSICAL STEROID SIGNALING REGULATES REPRODUCTION}

\section{Lordosis Behavior}

Lordosis is a behavior indicating sexual receptivity that is displayed by female rodents under certain physiological conditions and in concert with appropriate sensory cues from a male. In gonadally intact female rodents, fluctuating levels of steroid hormones such as E2 and P4 induce changes in neuronal structure and signaling that allows for the expression of lordosis, indicating the ability of the female to engage in copulation (96). Sexual 


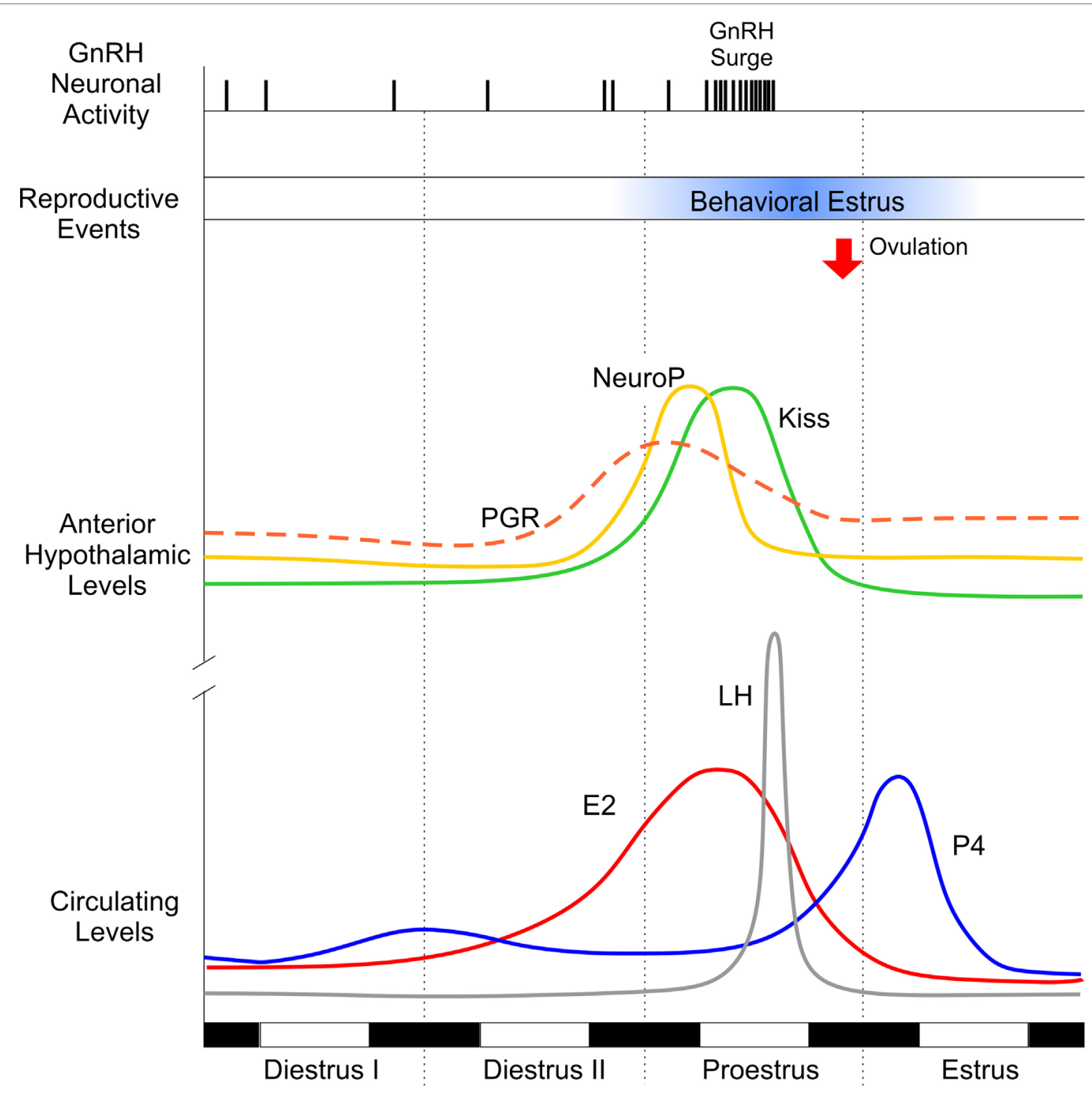

FIGURE 2 | Key factors underlying ovulation and sexual behavior in the female rodent across the rodent estrous cycle. Dark bars represent night time; light bars represent daytime. Diestrus I and II are marked by low levels of circulating (lower panel) hormones, such as estradiol (E2, red line), progesterone (P4, blue line), and luteinizing hormone (LH, gray line). Similarly, hypothalamic levels of P4 (neuroP, yellow line), progesterone receptor (PGR, orange dashed line), and kisspeptin (Kiss1, green line) are relatively low. Circulating E2 levels begin to rise (secondary to the development of ovarian follicles), triggering upregulation of PGR and Kiss1 in the anterior hypothalamus. E2 peaks on proestrus, inducing rapid synthesis of neuroP in hypothalamic astrocytes. In addition to the stimulatory effects of E2, the rise in local hypothalamic levels of neuroP augments Kiss1 expression, culminating in a gonadotropin-releasing hormone (GnRH) surge, which triggers surge release of LH from the pituitary and ovulation (red arrow). Note that peripheral P4 does not peak until after the LH surge triggering ovulation, supporting the idea that the critical source of preovulatory P4 is hypothalamic (neuroP). Behavioral estrus (blue bar) marks the height of female sexual receptivity (lordosis behavior), beginning after the peak of E2 and lasting until the morning of estrus.

receptivity as measured by lordosis behavior can be elicited by a variety of steroid priming paradigms in ovx rodents [for review, see Ref. (97)]. The typical pattern of steroid priming involves daily low doses of estradiol benzoate for 1-4 days, followed by a dose of P4, which induces sexual receptivity 4 h later [e.g., Ref. (98)]. However, $3 \mathrm{~V}$ administration of P4 can induce lordosis behavior with $30 \mathrm{~min}$ [(99); reviewed in Ref. (3)]. While E2 alone is sufficient to induce lordosis behavior, larger doses of E2 are needed to induce receptivity [e.g., Ref. (100-102)]. It is becoming clear that different circuits are activated by E2 alone vs. E2 + P4 treatment (3). Finally, it should be appreciated that P4 has dual effects on lordosis: facilitation of E2 and subsequent termination of the behavior (103).

\section{Ovulation}

\section{E2-Positive Feedback}

The neural mechanism underlying ovulation is a classic example of the interdependence of E2 and P4 in regulation of reproduction. Ovulation is triggered by surge release of $\mathrm{GnRH}$ from neurons in the hypothalamus, which in turn stimulate 
pituitary gonadotrophs to release LH. This surge of LH acts on the ovary, leading to release of a mature follicle. It has been well established that E2 affects GnRH neurons via both positive and negative feedback (104) albeit through distinct neuronal populations in the hypothalamus. This E2-regulated feedback is sex specific: males display only negative feedback in response to rising E2 levels (104-106), whereas females are capable of negative and positive feedback (107-110). This sex difference in LH surge capability is mirrored anatomically: male brains contain far fewer neurons in the AVPV, which is part of the rostral periventricular continuum of the third ventricle (RP3V) E2-positive feedback circuit in rodents; (111). In addition to this striking anatomical difference, there are other notable sex differences, such as E2-induced CREB phosphorylation in female, but not male, GnRH neurons (112). Ablation of this CREB signaling in GnRH neurons results in decreased fertility in females, but not males $(113,114)$. These in vivo results indicate an activation of GnRH neurons subsequent to E2 stimulation; they do not imply a direct action of E2 on $\mathrm{GnRH}$ neurons. While ER $\beta$ is expressed in GnRH neurons, the critical receptor, $E R \alpha$, is not $(115,116)$. These results demonstrate the summation of central E2 actions at the level of GnRH neurons.

More recently, the sequence of hormone signaling within the hypothalamus has been uncovered: E2 stimulates neuroP synthesis and upregulates PGR (Figures 2 and 3). Indeed, that both ER $\alpha$ and PGR are necessary for reproductive function is revealed by studies using PRKO and ER $\alpha$ knockout mice. These models demonstrate the requirement of both PGR and ER $\alpha$ for successful reproduction. Female mice with ER $\alpha$ deletion do not exhibit estrous cycles and fail to reproduce, thereby implicating the need for ER $\alpha$ signaling in estrogen-positive feedback $(117,118)$. However, a more specific knockout, with altered DNA-binding domain in the estrogen response element (ERE) suggests that non-classical, extra-ERE E2 signaling accounts for a substantial component of E2-negative feedback, via regulation of GnRH neuron firing $(119,120)$. Together, these findings indicate clear roles for both classical, nuclear-initiated E2 signaling and non-classical, membrane-initiated E2 signaling. In addition to
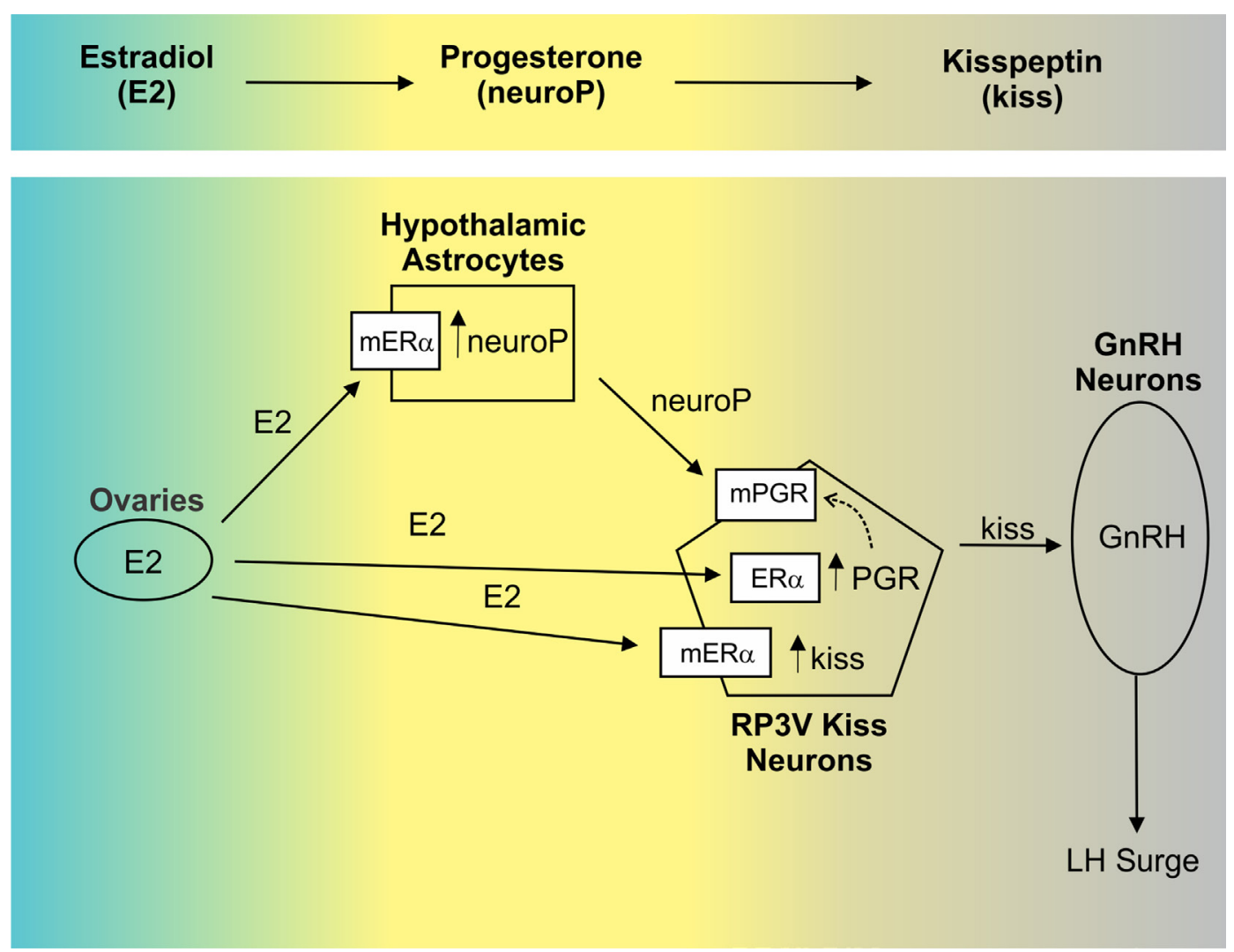

FIGURE 3 | The order of hypothalamic signaling underlying the luteinizing hormone (LH) surge in the rodent. Estradiol (E2) upregulates progesterone receptor (PGR) in the anterior hypothalamus [e.g., Ref. (92, 93)], though the cell types in which this occurs was unknown. Recently, evidence has emerged indicating that E2-induced PGR occurs in RP3V kisspeptin (Kiss1) neurons (94) via membrane-localized ER $\alpha \mathrm{mER} \alpha$; (18)]. In this population, the neuropeptide Kiss1 is also induced by E2 (95). In vitro, E2 up regulation of Kiss1 was demonstrated to occur through activation of mER $\alpha$, while PGR induction depended on classical signaling through nuclear estrogen receptor $\alpha(E R \alpha)$ (18). PGR can then translocate to the membrane (dashed arrow). In addition to its actions in neurons, E2 also facilitates synthesis of progesterone (neuroP) within hypothalamic astrocytes via activation of $\mathrm{mER} \alpha$. While local synthesis of neuroP is critical to the LH surge [e.g., Ref. (73)] its cellular targets are not established. We hypothesize that neuroP acts locally within Kiss1 neurons (via mPGR) to augment E2 induction of Kiss1, which then activates gonadotropin-releasing hormone $(\mathrm{GnRH})$ neurons. In vitro, immortalized Kiss1 neurons express PGR on the membrane and selective activation of PGR (using R5020) affects these cells within minutes supporting a functional role for membrane-localized PGR (mPGR in figure). 


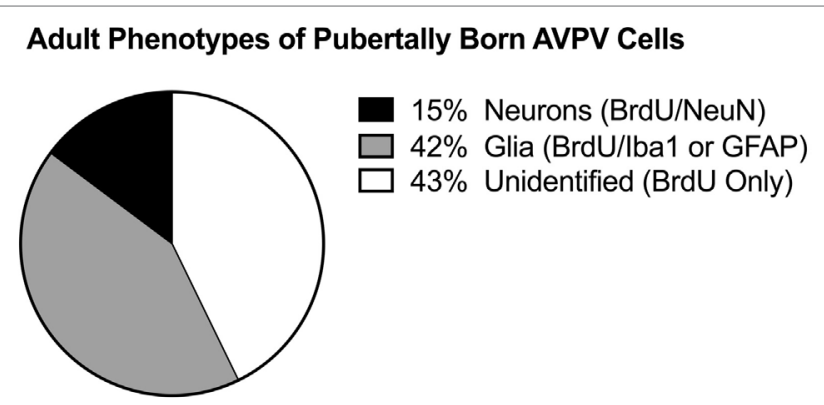

FIGURE 4 | Pubertally born cells. Differentiation of pubertally born cells in the female rat anteroventral periventricular nucleus (AVPV). Female SpragueDawley rats were treated during puberty (P28-P56) with the thymidine analog, bromodeoxyuridine (BrdU), to label newly proliferated cells, then sacrificed in adulthood (P77) to examine survival and differentiation of these cells in the AVPV. Pie chart represents the mean proportion of pubertally born cells (BrdU-ir cells) that are glia (express Iba1-ir or GFAP-ir), neurons (express NeuN), or neither (unidentified, BrdU only). Figure modified and reproduced from Ref. (91), used with permission.

estrogens' actions, several studies have indicated that PGR is also important. Namely, PRKO mice fail to mount LH surges in response to E2 treatment (121), as do rats following pharmacological or oligodeoxynucleotide blockade of P4/PGR signaling (122). These data support the dependence of E2 on downstream P4 signaling (Figure 3). The ER $\alpha \mathrm{KO}$ mice demonstrate an interdependence of $\mathrm{ER} \alpha$ and PGR, as PGR is markedly reduced (60\%) in $\mathrm{ER} \alpha \mathrm{KO}$ mice compared to wild-type controls. Additionally, P4 treatments augment and advance the LH surge $(123,124)$.

\section{Hypothalamic Microcircuitry Controlling the LH Surge}

Gonadotropin-releasing hormone neurons in the preoptic area of the hypothalamus release $\mathrm{GnRH}$ into the hypothalamichypophyseal portal system. Release of LH from the pituitary is temporally correlated with that of $\mathrm{GnRH}$, including both low-level/pulsatile and surge release (125), making plasma LH measurements reliable indicators of central activity. Rising levels of E2 lead to surge release of GnRH and $\mathrm{LH}$ [estrogen-positive feedback; (126-128)]. This is not achieved through direct activation of GnRH neurons, as they do not express ER $\alpha$, the critical ER mediating positive feedback (111). Instead, an upstream population of cells must mediate E2 feedback. This upstream population is now generally accepted to be neurons expressing kisspeptin (Kiss1) in the RP3V that includes the AVPV [reviewed in Ref. (129)]. Kiss1 neurons are the accepted site for E2-positive feedback based on the following evidence:

1. E2 induces Kiss1 expression in the RP3V in vivo [reviewed in Ref. (130)].

2. RP3V Kiss1 neurons express $\operatorname{ER} \alpha(94,95,120,131)$, the critical ER for positive feedback (111).

3. Kiss1 neurons express PGR, the PGR associated with positive feedback (132)

4. RP3V Kiss1 neurons project to GnRH neurons $(111,133)$, which express the Kiss1 receptor [GPR54/Kiss1R; (134)].
Importantly, this expression of GPR54 in GnRH neurons is critical for fertility [(135, 136); also see Ref. (137)].

5. Kiss1 is the most potent activator of GnRH neurons [e.g., Ref. (138)].

\section{Cellular Targets}

While rising E2 is a necessary precursor to the LH surge, preovulatory P4 signaling is similarly important [Figures $\mathbf{2}$ and 3; (73, 139-142)]. As previously described, the classical PGR is the critical receptor for multiple reproductive processes, including the LH surge. Likewise, Kiss1 signaling is requisite and is likely to be downstream of P4/neuroP signaling because Kiss1 neurons directly and potently stimulate GnRH neurons [e.g., Ref. (138)] and because Kiss1 consistently elicits an LH surge (143-145). However, the cellular targets mediating interactions between neuroP, and PGR are only now becoming clear. E2 stimulates PGR in the anterior hypothalamus and simultaneously induces neuroP production in astrocytes. From here, Kiss1 stimulates $\mathrm{GnRH}$ neurons, but it is not clear how Kiss1-induced GnRH activity is linked to both PGR upregulation and neuroP production. Our laboratory hypothesizes that Kiss1 neurons express the critical PGR receptors themselves, and E2 and neuroP signaling is integrated within Kiss1 neurons.

\section{E2-Induced PGR Expression in Kiss1 Neurons}

Dual label immunohistochemistry studies show extensive PGR expression in arcuate nucleus [e.g., Ref. (146)] and in RP3V kisspeptin neurons $(94,147)$. Zhang and colleagues demonstrate co-localization of PGR in RP3V Kiss1 neurons (94), but only in tissue taken from animals in proestrus (high E2 levels). There was no co-localization in tissue taken from animals in diestrus (e.g., when levels of E2 are low), suggesting an E2-induced increase in PGR expression in RP3V Kiss1 neurons. Our laboratory has determined that PGR expression is increased by E2 in mHypoA51 cells, an in vitro model of RP3V Kiss1 neurons. mHypoA51s are immortalized cells derived from adult, female mouse hypothalamus that exhibit a robust increase in PGR expression following stimulation with E2 (18), consistent with the idea that E2 induces PGR in RP3V Kiss1 neurons in vivo.

\section{PGR Expression in Kiss1 Neurons Is Critical for the LH Surge}

We have shown that in immortalized Kiss1 neurons PGR does traffic to the cell membrane (41). Furthermore, this membranelocalized classical PGR is critical for full Kiss1 expression and possibly release. Stimulation with E2 induced PGR in these cells, after which a 5-min stimulation with R5020 (a selective PGR agonist) caused Erk1/2 phosphorylation (41). This was prevented with Src antagonist PP2, suggesting a PGR/Src interaction. PGR has been shown to associate with Src, although the physiological implications of this association are still emerging (42). Additionally, a number of other membrane progesteronebinding proteins are expressed in the hypothalamus, but their role in Kiss1 neuron function has not been elucidated. Kiss1 neurons in vitro ( $\mathrm{mHypoA51}$ cells) express $\mathrm{mPR} \alpha$ and $\mathrm{mPR} \beta$; however, the expression of these receptors in mHypoA51 Kiss1 
neurons is not modulated by E2, suggesting that their role may not be directly related to modulation of GnRH release (41). In vivo, $\mathrm{mPR} \beta$ is induced by $\mathrm{E} 2$ in the anterior hypothalamus, though this may reflect upregulation in non-Kiss1 cells, as a number of cell types (neuronal and non-neuronal) are present in whole tissue (29). Therefore, while there is a clear role for PGR in the Kiss 1 circuit governing ovulation, we have yet to determine how mPRs might be involved. It will also be interesting to learn the details of PGR signaling (i.e., to what extent membrane vs. classical signaling is involved, and which intracellular cascades are activated).

Two groups have recently demonstrated the necessity of PGR expression in Kiss1 neurons using a genetic knockout model. Kiss1 PRKO mice lack PGR expression specifically within Kiss1 cells and are, perhaps surprisingly, not infertile; however, they do not display the characteristic OVX + E2-induced LH surge $(132,148)$. This in vivo evidence solidifies the importance of classical PGR in Kiss1 neurons for the LH surge. These studies represent an important breakthrough in understanding the hypothalamic microcircuitry governing the LH surge. PGR within Kiss1 neurons represents the critical site for P4 action underlying the LH surge. Some questions remain, however: What subcellular localization is important in this process? Is membrane PGR involved? Moving forward, it will be interesting to learn the answers to these questions and to know the extent to which membrane P4 and neuroP signaling influence gonadotropin release in the female rodent.

\section{CONCLUSION}

This review focuses on $\mathrm{P} 4$ membrane-initiated signaling regulating reproduction, especially within the CNS. Both in vivo and in vitro studies demonstrate that PGR expressed in Kiss1 neurons of the RP3V are important for E2-positive feedback on the LH surge. Kiss1/neurokinin B/dynorphin (KNDy) neurons in the ARH appear to mediate aspects of negative feedback [e.g., Ref. (149); see Ref. (150) for review]. Studies from our laboratory underscore the importance of E2-induced neuroP synthesis in

\section{REFERENCES}

1. Katzenellenbogen JA, Katzenellenbogen BS. Nuclear hormone receptors: ligand-activated regulators of transcription and diverse cell responses. Chem Biol (1996) 3(7):529-36. doi:10.1016/S1074-5521(96)90143-X

2. Micevych P, Sinchak K. Estradiol regulation of progesterone synthesis in the brain. Mol Cell Endocrinol (2008) 290(1-2):44-50. doi:10.1016/j. mce.2008.04.016

3. Rudolph LM, Cornil CA, Mittelman-Smith MA, Rainville JR, Remage-Healey L, Sinchak K, et al. Actions of steroids: new neurotransmitters. J Neurosci (2016) 36(45):11449-58. doi:10.1523/jneurosci.2473-16.2016

4. Abraham IM, Todman MG, Korach KS, Herbison AE. Critical in vivo roles for classical estrogen receptors in rapid estrogen actions on intracellular signaling in mouse brain. Endocrinology (2004) 145(7):3055-61. doi:10.1210/ en.2003-1676

5. Boulware MI, Weick JP, Becklund BR, Kuo SP, Groth RD, Mermelstein PG. Estradiol activates group I and II metabotropic glutamate receptor signaling, leading to opposing influences on cAMP response element-binding protein. J Neurosci (2005) 25(20):5066-78. doi:10.1523/JNEUROSCI. 1427-05.2005 female hypothalamic astrocytes and its role in activating the LH surge. In Kiss 1 neurons, neuroP acts on PGRs to augment the E2 induction of Kiss1 expression and release (see Figure 3). Significantly, in prepubertal astrocytes, E2 is not capable of facilitating neuroP synthesis in females. Following puberty, female, but not male, hypothalamic astrocytes are highly responsive to E2. This shift appears to be due to a new population of astrocytes that are born during puberty and adulthood. What makes these pubertally born astrocytes competent to have E2-facilitated neuroP synthesis will require further experimentation. Interestingly, Kiss1 neurons, at least in vitro, express mPRs. While knockdown of the PGR abrogates the LH and reproduction, mPR function in Kiss1 neurons at this juncture remains unclear. PGRs are induced through direct nuclear action of E2, in our immortalized Kiss1 neuron model (18). A population of these PGRs is transported to the cell membrane and is stimulated by neuroP. The downstream signaling mechanisms appear to involve activation of Src, ERK1/2, and intracellular calcium. Thus, while there are many questions to address, it is now clear that membrane-initiated P4 signaling is involved in regulation of the LH surge - a cornerstone of P4 action. Similar to E2, it is likely that as research into P4 signaling continues, we will discover that this steroid can function in neurotransmitter-like fashion, and both classical and nonclassical mechanisms of action are integrated to regulate critical reproductive functions, and many other neural phenomena in both PNS and CNS.

\section{AUTHOR CONTRIBUTIONS}

All authors (MM-S, LR, MM, and PM) contributed to this work through critical review of current and historical literature.

\section{ACKNOWLEDGMENTS}

This work was supported by NIH Grants HD042635 and HD007228. All appropriate permissions have been obtained from the copyright holders of any work that has been reproduced in this manuscript.

6. Kelly MJ, Levin ER. Rapid actions of plasma membrane estrogen receptors. Trends Endocrinol Metab (2001) 12(4):152-6. doi:10.1016/ S1043-2760(01)00377-0

7. Levin ER. Cell localization, physiology, and nongenomic actions of estrogen receptors. J Appl Physiol (2001) 91(4):1860-7.

8. Micevych PE, Wong AM, Mittelman-Smith MA. Estradiol membraneinitiated signaling and female reproduction. Compr Physiol (2015) 5(3):1211-22. doi:10.1002/cphy.c140056

9. Micevych P, Dominguez R. Membrane estradiol signaling in the brain. Front Neuroendocrinol (2009) 30(3):315-27. doi:10.1016/j.yfrne.2009.04.011

10. Micevych PE, Kelly MJ. Membrane estrogen receptor regulation of hypothalamic function. Neuroendocrinology (2012) 96(2):103-10. doi:10.1159/000338400

11. Mermelstein PG, Micevych PE. Nervous system physiology regulated by membrane estrogen receptors. Rev Neurosci (2008) 19(6):413-24. doi:10.1515/REVNEURO.2008.19.6.413

12. Schumacher M, Weill-Engerer S, Liere $P$, Robert F, Franklin RJ, Garcia-Segura LM, et al. Steroid hormones and neurosteroids in normal and pathological aging of the nervous system. Prog Neurobiol (2003) 71(1):3-29. doi:10.1016/j.pneurobio.2003.09.004 
13. Schumacher M, Guennoun R, Robert F, Carelli C, Gago N, Ghoumari A, et al. Local synthesis and dual actions of progesterone in the nervous system: neuroprotection and myelination. Growth Horm IGF Res (2004) 14(Suppl A):S18-33. doi:10.1016/j.ghir.2004.03.007

14. Szego CM, Davis JS. Adenosine 3',5'-monophosphate in rat uterus: acute elevation by estrogen. Proc Natl Acad Sci US A (1967) 58(4):1711-8. doi:10.1073/ pnas.58.4.1711

15. Eckersell CB, Popper P, Micevych PE. Estrogen-induced alteration of mu-opioid receptor immunoreactivity in the medial preoptic nucleus and medial amygdala. J Neurosci (1998) 18:3967-76.

16. Dewing P, Boulware MI, Sinchak K, Christensen A, Mermelstein PG, Micevych P. Membrane estrogen receptor-alpha interactions with metabotropic glutamate receptor 1a modulate female sexual receptivity in rats. J Neurosci (2007) 27(35):9294-300. doi:10.1523/JNEUROSCI.0592-07.2007

17. Vasudevan N, Kow LM, Pfaff DW. Early membrane estrogenic effects required for full expression of slower genomic actions in a nerve cell line. Proc Natl Acad Sci U S A (2001) 98(21):12267-71. doi:10.1073/pnas.221449798

18. Mittelman-Smith MA, Wong AM, Kathiresan AS, Micevych PE. Classical and membrane-initiated estrogen signaling in an in vitro model of anterior hypothalamic kisspeptin neurons. Endocrinology (2015) 156(6):2162-73. doi:10.1210/en.2014-1803

19. Kow LM, Pfaff DW. The membrane actions of estrogens can potentiate their lordosis behavior-facilitating genomic actions. Proc Natl Acad Sci U S A (2004) 101(33):12354-7. doi:10.1073/pnas.0404889101

20. Bondar G, Kuo J, Hamid N, Micevych P. Estradiol-induced estrogen receptor-alpha trafficking. J Neurosci (2009) 29(48):15323-30. doi:10.1523/ JNEUROSCI.2107-09.2009

21. Boulware MI, Kordasiewicz H, Mermelstein PG. Caveolin proteins are essential for distinct effects of membrane estrogen receptors in neurons. J Neurosci (2007) 27(37):9941-50. doi:10.1523/JNEUROSCI.1647-07.2007

22. Razandi M, Alton G, Pedram A, Ghonshani S, Webb P, Levin ER. Identification of a structural determinant necessary for the localization and function of estrogen receptor alpha at the plasma membrane. Mol Cell Biol (2003) 23(5):1633-46. doi:10.1128/MCB.23.5.1633-1646.2003

23. Meitzen J, Luoma JI, Boulware MI, Hedges VL, Peterson BM, Tuomela K, et al. Palmitoylation of estrogen receptors is essential for neuronal membrane signaling. Endocrinology (2013) 154(11):4293-304. doi:10.1210/ en.2013-1172

24. Parsons B, MacLusky NJ, Krey L, Pfaff DW, McEwen BS. The temporal relationship between estrogen-inducible progestin receptors in the female rat brain and the time course of estrogen activation of mating behavior. Endocrinology (1980) 107(3):774-9. doi:10.1210/endo-107-3-774

25. Smith SS, Waterhouse BD, Chapin JK, Woodward DJ. Progesterone alters GABA and glutamate responsiveness: a possible mechanism for its anxiolytic action. Brain Res (1987) 400(2):353-9. doi:10.1016/0006-8993 (87) $90634-2$

26. Smith SS, Waterhouse BD, Woodward DJ. Sex steroid effects on extrahypothalamic CNS. II. Progesterone, alone and in combination with estrogen, modulates cerebellar responses to amino acid neurotransmitters. Brain Res (1987) 422(1):52-62. doi:10.1016/0006-8993(87)90539-7

27. Petitti N, Etgen AM. Progesterone depression of norepinephrine-stimulated cAMP accumulation in hypothalamic slices. Brain Res Mol Brain Res (1989) 5(2):109-19. doi:10.1016/0169-328X(89)90002-8

28. Schumacher M, Coirini H, Pfaff DW, McEwen BS. Behavioral effects of progesterone associated with rapid modulation of oxytocin receptors. Science (1990) 250:691-4. doi:10.1126/science.2173139

29. Sleiter N, Pang Y, Park C, Horton TH, Dong J, Thomas P, et al. Progesterone receptor A (PRA) and PRB-independent effects of progesterone on gonadotropin-releasing hormone release. Endocrinology (2009) 150(8):3833-44. doi:10.1210/en.2008-0774

30. Bashour NM, Wray S. Progesterone directly and rapidly inhibits GnRH neuronal activity via progesterone receptor membrane component 1 . Endocrinology (2012) 153(9):4457-69. doi:10.1210/en.2012-1122

31. Meiri H. Is synaptic transmission modulated by progesterone? Brain Res (1986) 385(1):193-6. doi:10.1016/0006-8993(86)91566-0

32. Meisel RL, Pfaff DW. RNA and protein synthesis inhibitors: effects on sexual behavior in female rats. Brain Res Bull (1984) 12(2):187-93. doi:10.1016/0361-9230(84)90188-6
33. Beyer C, Gonzalez-Mariscal G. Elevation in hypothalamic cyclic AMP as a common factor in the facilitation of lordosis in rodents: a working hypothesis. Ann N Y Acad Sci (1986) 474:270-81. doi:10.1111/j.1749-6632.1986. tb28018.x

34. Ke FC, Ramirez VD. Membrane mechanism mediates progesterone stimulatory effect on LHRH release from superfused rat hypothalami in vitro. Neuroendocrinology (1987) 45(6):514-7. doi:10.1159/000124784

35. Picazo O, Fernandez-Guasti A. Anti-anxiety effects of progesterone and some of its reduced metabolites: an evaluation using the burying behavior test. Brain Res (1995) 680(1-2):135-41. doi:10.1016/0006-8993(95)00254-N

36. Pearson Murphy BE, Steinberg SI, Hu FY, Allison CM. Neuroactive ring A-reduced metabolites of progesterone in human plasma during pregnancy: elevated levels of 5 alpha-dihydroprogesterone in depressed patients during the latter half of pregnancy. J Clin Endocrinol Metab (2001) 86(12):5981-7. doi:10.1210/jcem.86.12.8122

37. Ciriza I, Carrero P, Frye CA, Garcia-Segura LM. Reduced metabolites mediate neuroprotective effects of progesterone in the adult rat hippocampus. The synthetic progestin medroxyprogesterone acetate (Provera) is not neuroprotective. J Neurobiol (2006) 66(9):916-28. doi:10.1002/neu.20293

38. Pedram A, Razandi M, Sainson RC, Kim JK, Hughes CC, Levin ER. A conserved mechanism for steroid receptor translocation to the plasma membrane. J Biol Chem (2007) 282(31):22278-88. doi:10.1074/jbc.M611877200

39. Mani SK, Mermelstein PG, Tetel MJ, Anesetti G. Convergence of multiple mechanisms of steroid hormone action. Horm Metab Res (2012) 44(8): 569-76. doi:10.1055/s-0032-1306343

40. Mani SK, Oyola MG. Progesterone signaling mechanisms in brain and behavior. Front Endocrinol (2012) 3:7. doi:10.3389/fendo.2012.00007

41. Mittelman-Smith MA, Wong AM, Micevych PE. Estrogen and progesterone integration in an in vitro model of RP3V kisspeptin neurons. Neuroendocrinology (2017). doi:10.1159/000471878

42. Boonyaratanakornkit V, Scott MP, Ribon V, Sherman L, Anderson SM, Maller JL, et al. Progesterone receptor contains a proline-rich motif that directly interacts with $\mathrm{SH} 3$ domains and activates c-Src family tyrosine kinases. Mol Cell (2001) 8(2):269-80. doi:10.1016/S1097-2765(01)00304-5

43. Boonyaratanakornkit V, McGowan E, Sherman L, Mancini MA, Cheskis BJ, Edwards DP. The role of extranuclear signaling actions of progesterone receptor in mediating progesterone regulation of gene expression and the cell cycle. Mol Endocrinol (2007) 21(2):359-75. doi:10.1210/me.2006-0337

44. Chaban V, Li J, McDonald J, Rapkin A, Micevych P. Estradiol attenuates ATPinduced increase of intracellular calcium through group II metabotropic glutamate receptors in rat DRG neurons. Soc Neuronsci (2007) 89(11):1707-10. doi:10.1002/jnr.22718

45. Zhu Y, Rice CD, Pang Y, Pace M, Thomas P. Cloning, expression, and characterization of a membrane progestin receptor and evidence it is an intermediary in meiotic maturation of fish oocytes. Proc Natl Acad Sci U S A (2003) 100(5):2231-6. doi:10.1073/pnas.0336132100

46. Thomas P. Characteristics of membrane progestin receptor alpha (mPRalpha) and progesterone membrane receptor component 1 (PGMRC1) and their roles in mediating rapid progestin actions. Front Neuroendocrinol (2008) 29(2):292-312. doi:10.1016/j.yfrne.2008.01.001

47. Petersen SL, Intlekofer KA, Moura-Conlon PJ, Brewer DN, Del Pino Sans J, Lopez JA. Nonclassical progesterone signalling molecules in the nervous system. J Neuroendocrinol (2013) 25(11):991-1001. doi:10.1111/jne.12060

48. Cahill MA. Progesterone receptor membrane component 1: an integrative review. J Steroid Biochem Mol Biol (2007) 105(1-5):16-36. doi:10.1016/j. jsbmb.2007.02.002

49. Pang Y, Dong J, Thomas P. Characterization, neurosteroid binding and brain distribution of human membrane progesterone receptors delta and \{epsilon\} (mPRdelta and mPR $\{$ epsilon\}) and mPRdelta involvement in neurosteroid inhibition of apoptosis. Endocrinology (2013) 154(1):283-95. doi:10.1210/ en.2012-1772

50. Thomas P, Pang Y, Dong J, Groenen P, Kelder J, de Vlieg J, et al. Steroid and $G$ protein binding characteristics of the seatrout and human progestin membrane receptor alpha subtypes and their evolutionary origins. Endocrinology (2007) 148(2):705-18. doi:10.1210/en.2006-0974

51. Thomas P, Pang Y. Membrane progesterone receptors: evidence for neuroprotective, neurosteroid signaling and neuroendocrine functions in neuronal cells. Neuroendocrinology (2012) 96(2):162-71. doi:10.1159/000339822 
52. Intlekofer KA, Petersen SL. Distribution of mRNAs encoding classical progestin receptor, progesterone membrane components 1 and 2, serpine mRNA binding protein 1, and progestin and ADIPOQ receptor family members 7 and 8 in rat forebrain. Neuroscience (2011) 172:55-65. doi:10.1016/j. neuroscience.2010.10.051

53. Zuloaga DG, Yahn SL, Pang Y, Quihuis AM, Oyola MG, Reyna A, et al. Distribution and estrogen regulation of membrane progesterone receptor-beta in the female rat brain. Endocrinology (2012) 153(9):4432-43. doi:10.1210/en.2012-1469

54. Thomas P, Zhu Y, Pace M. Progestin membrane receptors involved in the meiotic maturation of teleost oocytes: a review with some new findings. Steroids (2002) 67(6):511-7. doi:10.1016/S0039-128X(01)00180-5

55. Tubbs C, Pace M, Thomas P. Expression and gonadotropin regulation of membrane progestin receptor alpha in Atlantic croaker (Micropogonias undulatus) gonads: role in gamete maturation. Gen Comp Endocrinol (2010) 165(1):144-54. doi:10.1016/j.ygcen.2009.06.017

56. Peluso JJ, Romak J, Liu X. Progesterone receptor membrane component-1 (PGRMC1) is the mediator of progesterone's antiapoptotic action in spontaneously immortalized granulosa cells as revealed by PGRMC1 small interfering ribonucleic acid treatment and functional analysis of PGRMC1 mutations. Endocrinology (2008) 149(2):534-43. doi:10.1210/en.2007-1050

57. Clark NC, Friel AM, Pru CA, Zhang L, Shioda T, Rueda BR, et al. Progesterone receptor membrane component 1 promotes survival of human breast cancer cells and the growth of xenograft tumors. Cancer Biol Ther (2016) 17(3):262-71. doi:10.1080/15384047.2016.1139240

58. Clark NC, Pru CA, Yee SP, Lydon JP, Peluso JJ, Pru JK. Conditional ablation of progesterone receptor membrane component 2 causes female premature reproductive senescence. Endocrinology (2017) 158(3):640-51. doi:10.1210/ en.2016-1701

59. Meyer C, Schmid R, Scriba PC, Wehling M. Purification and partial sequencing of high-affinity progesterone-binding site(s) from porcine liver membranes. Eur J Biochem (1996) 239(3):726-31. doi:10.1111/j.1432-1033.1996.0726u.x

60. Krebs CJ, Jarvis ED, Chan J, Lydon JP, Ogawa S, Pfaff DW. A membraneassociated progesterone-binding protein, $25-\mathrm{Dx}$, is regulated by progesterone in brain regions involved in female reproductive behaviors. Proc Natl Acad Sci U S A (2000) 97(23):12816-21. doi:10.1073/pnas.97.23.12816

61. Peluso JJ, Pappalardo A, Losel R, Wehling M. Progesterone membrane receptor component 1 expression in the immature rat ovary and its role in mediating progesterone's antiapoptotic action. Endocrinology (2006) 147(6):3133-40. doi:10.1210/en.2006-0114

62. Intlekofer KA, Petersen SL. 17beta-estradiol and progesterone regulate multiple progestin signaling molecules in the anteroventral periventricular nucleus, ventromedial nucleus and sexually dimorphic nucleus of the preoptic area in female rats. Neuroscience (2011) 176:86-92. doi:10.1016/j. neuroscience.2010.12.033

63. Thomas P, Pang Y, Dong J. Enhancement of cell surface expression and receptor functions of membrane progestin receptor alpha (mPRalpha) by progesterone receptor membrane component 1 (PGRMC1): evidence for a role of PGRMC1 as an adaptor protein for steroid receptors. Endocrinology (2014) 155(3):1107-19. doi:10.1210/en.2013-1991

64. Mifsud W, Bateman A. Membrane-bound progesterone receptors contain a cytochrome b5-like ligand-binding domain. Genome Biol (2002) 3(12):RESEARCH0068. doi:10.1186/gb-2002-3-12-research0068

65. Ahmed IS, Chamberlain C, Craven RJ. S2R(Pgrmc1): the cytochrome-related sigma-2 receptor that regulates lipid and drug metabolism and hormone signaling. Expert Opin Drug Metab Toxicol (2012) 8(3):361-70. doi:10.151 7/17425255.2012.658367

66. Baulieu EE. Neurosteroids: a new function in the brain. Biol Cell (1991) 71(1-2):3-10. doi:10.1016/0248-4900(91)90045-O

67. Naftolin F, Horvath TL, Jakab RL, Leranth C, Harada N, Balthazart J. Aromatase immunoreactivity in axon terminals of the vertebrate brain. An immunocytochemical study on quail, rat, monkey and human tissues. Neuroendocrinology (1996) 63(2):149-55. doi:10.1159/000126951

68. Charlier TD, Cornil CA, Patte-Mensah C, Meyer L, Mensah-Nyagan AG, Balthazart J. Local modulation of steroid action: rapid control of enzymatic activity. Front Neurosci (2015) 9:83. doi:10.3389/fnins.2015.00083

69. Sato SM, Woolley CS. Acute inhibition of neurosteroid estrogen synthesis suppresses status epilepticus in an animal model. Elife (2016) 5:e12917. doi:10.7554/eLife.12917
70. Tuscher JJ, Szinte JS, Starrett JR, Krentzel AA, Fortress AM, Remage-Healey L, et al. Inhibition of local estrogen synthesis in the hippocampus impairs hippocampal memory consolidation in ovariectomized female mice. Horm Behav (2016) 83:60-7. doi:10.1016/j.yhbeh.2016.05.001

71. de Bournonville C, Balthazart J, Ball GF, Cornil CA. Non-ovarian aromatization is required to activate female sexual motivation in testosterone-treated ovariectomized quail. Horm Behav (2016) 83:45-59. doi:10.1016/j. yhbeh.2016.05.011

72. Dickens MJ, de Bournonville C, Balthazart J, Cornil CA. Relationships between rapid changes in local aromatase activity and estradiol concentrations in male and female quail brain. Horm Behav (2014) 65(2):154-64. doi:10.1016/j.yhbeh.2013.12.011

73. Micevych P, Sinchak K, Mills RH, Tao L, LaPolt P, Lu JK. The luteinizing hormone surge is preceded by an estrogen-induced increase of hypothalamic progesterone in ovariectomized and adrenalectomized rats. Neuroendocrinology (2003) 78(1):29-35. doi:10.1159/000071703

74. Buckingham JC, Dohler KD, Wilson CA. Activity of the pituitaryadrenocortical system and thyroid gland during the oestrous cycle of the rat. J Endocrinol (1978) 78(3):359-66. doi:10.1677/joe.0.0780359

75. Mahesh VB, Brann DW. Regulation of the preovulatory gonadotropin surge by endogenous steroids. Steroids (1998) 63(12):616-29. doi:10.1016/ S0039-128X(98)00075-0

76. Putnam CD, Brann DW, Mahesh VB. Acute activation of the adrenocorticotropin-adrenal axis: effect on gonadotropin and prolactin secretion in the female rat. Endocrinology (1991) 128(5):2558-66. doi:10.1210/ endo-128-5-2558

77. Shaikh AA, Shaikh SA. Adrenal and ovarian steroid secretion in the rat estrous cycle temporally related to gonadotropins and steroid levels found in peripheral plasma. Endocrinology (1975) 96(1):37-44. doi:10.1210/ endo-96-1-37

78. Micevych P, Sinchak K. Synthesis and function of hypothalamic neuroprogesterone in reproduction. Endocrinology (2008) 149(6):2739-42. doi:10.1210/en.2008-0011

79. Micevych PE, Sinchak K. The neurosteroid progesterone underlies estrogen positive feedback of the LH surge. Front Endocrinol (2011) 2:90. doi:10.3389/ fendo. 2011.00090

80. Paaske LK, Micevych PE, Sinchak K, editors. Kisspeptin mediates neuroprogesterone induction of the luteinizing hormone surge. The Endocrine Society's 95th Annual Meeting \& Expo. San Francisco, CA (2013).

81. Paaske LK, Chuon T, Micevych P, Sinchak K, editors. AVPV Kisspeptin Neurons Mediate Neuroprogesterone Induction of the Luteinizing Hormone Surge. Washington, DC: Neuroscience Meeting Planner (2014).

82. Chen C, Kuo J, Wong A, Micevych P. Estradiol modulates translocator protein (TSPO) and steroid acute regulatory protein (StAR) via protein kinase A (PKA) signaling in hypothalamic astrocytes. Endocrinology (2014) 155(8):2976-85. doi:10.1210/en.2013-1844

83. Itzhak Y, Baker L, Norenberg MD. Characterization of the peripheral-type benzodiazepine receptors in cultured astrocytes: evidence for multiplicity. Glia (1993) 9(3):211-8. doi:10.1002/glia.440090306

84. Papadopoulos V, Baraldi M, Guilarte TR, Knudsen TB, Lacapere JJ, Lindemann $\mathrm{P}$, et al. Translocator protein $(18 \mathrm{kDa})$ : new nomenclature for the peripheral-type benzodiazepine receptor based on its structure and molecular function. Trends Pharmacol Sci (2006) 27(8):402-9. doi:10.1016/j. tips.2006.06.005

85. Selvaraj V, Stocco DM, Tu LN. Minireview: translocator protein (TSPO) and steroidogenesis: a reappraisal. Mol Endocrinol (2015) 29(4):490-501. doi:10.1210/me.2015-1033

86. Kuo J, Hamid N, Bondar G, Dewing P, Clarkson J, Micevych P. Sex differences in hypothalamic astrocyte response to estradiol stimulation. Biol Sex Differ (2010) 1(1):7. doi:10.1186/2042-6410-1-7

87. Hoffman GE, Le WW, Schulterbrandt T, Legan SJ. Estrogen and progesterone do not activate Fos in AVPV or LHRH neurons in male rats. Brain Res (2005) 1054(2):116-24. doi:10.1016/j.brainres.2005.06.082

88. Andrews WW, Ojeda SR. A detailed analysis of the serum luteinizing hormone secretory profile in conscious, free-moving female rats during the time of puberty. Endocrinology (1981) 109(6):2032-9. doi:10.1210/endo-109-6-2032

89. Micevych PE, Chaban V, Ogi J, Dewing P, Lu JK, Sinchak K. Estradiol stimulates progesterone synthesis in hypothalamic astrocyte cultures. Endocrinology (2007) 148(2):782-9. doi:10.1210/en.2006-0774 
90. Kuo J, Hamid N, Bondar G, Prossnitz ER, Micevych P. Membrane estrogen receptors stimulate intracellular calcium release and progesterone synthesis in hypothalamic astrocytes. J Neurosci (2010) 30(39):12950-7. doi:10.1523/ JNEUROSCI.1158-10.2010

91. Mohr MA, Garcia FL, DonCarlos LL, Sisk CL. Neurons and glial cells are added to the female rat anteroventral periventricular nucleus during puberty. Endocrinology (2016) 157(6):2393-402. doi:10.1210/en.2015-2012

92. Simerly RB, Carr AM, Zee MC, Lorang D. Ovarian steroid regulation of estrogen and progesterone receptor messenger ribonucleic acid in the anteroventral periventricular nucleus of the rat. J Neuroendocrinol (1996) 8(1):45-56. doi:10.1111/j.1365-2826.1996.tb00685.x

93. Shughrue PJ, Lane MV, Merchenthaler I. Regulation of progesterone receptor messenger ribonucleic acid in the rat medial preoptic nucleus by estrogenic and antiestrogenic compounds: an in situ hybridization study. Endocrinology (1997) 138(12):5476-84. doi:10.1210/endo.138.12.5595

94. Zhang J, Yang L, Lin N, Pan X, Zhu Y, Chen X. Aging-related changes in RP3V kisspeptin neurons predate the reduced activation of GnRH neurons during the early reproductive decline in female mice. Neurobiol Aging (2014) 35(3):655-68. doi:10.1016/j.neurobiolaging.2013.08.038

95. Smith JT, Cunningham MJ, Rissman EF, Clifton DK, Steiner RA. Regulation of Kiss1 gene expression in the brain of the female mouse. Endocrinology (2005) 146(9):3686-92. doi:10.1210/en.2005-0488

96. Beach FA. Hormones and Behavior. New York: Paul B. Hoeber (1948).

97. Micevych P, Sinchak K. Temporal and concentration dependent estradiol effects on neural pathways mediating sexual receptivity. J Neuroendocrinol (2013) 25(11):1012-23. doi:10.1111/jne.12103

98. Whalen RE. Estrogen-progesterone induction of mating in female rats. Horm Behav (1974) 5(2):157-62. doi:10.1016/0018-506X(74)90040-3

99. Mani SK, Blaustein JD, Omalley BW. Progesterone receptor function from a behavioral perspective. Horm Behav (1997) 31(3):244-55. doi:10.1006/ hbeh.1997.1393

100. Clemens LG, Weaver DR. The role of gonadal hormone in the activation of feminine sexual behavior. In: Adler N, Pfaff D, Goy RW, editors. Handbook of Behavioral Neurobiology. (Vol. 7), New York: Plenum Press (1985). p. 183-227.

101. Pfaff D. Nature of sex hormone effects on rat sex behavior: specificity of effects and individual patterns of response. J Comp Physiol Psychol (1970) 73(3):349-58. doi:10.1037/h0030242

102. Quadagno DM, McCullough J, Langan R. The effect of varying amounts of exogenous estradiol benzoate on estrous behavior in the rat. Horm Behav (1972) 3(3):175-9. doi:10.1016/0018-506X(72)90029-3

103. Sodersten P, Eneroth P. Serum levels of oestradiol-17 beta and progesterone in relation to receptivity in intact and ovariectomized rats. J Endocrinol (1981) 89(1):45-54. doi:10.1677/joe.0.0890045

104. Herbison A. Physiology of the gonadotropin-releasing hormone neuronal network. In: Neill J, editor. Physiology of Reproduction. New Hampshire: Elsevier (2006). p. 1415-82.

105. Couse JE, Mahato D, Eddy EM, Korach KS. Molecular mechanism of estrogen action in the male: insights from the estrogen receptor null mice. Reprod Fertil Dev (2001) 13(4):211-9. doi:10.1071/RD00128

106. Herbison AE. Multimodal influence of estrogen upon gonadotropinreleasing hormone neurons. Endocr Rev (1998) 19(3):302-30.

107. Legan SJ, Coon GA, Karsch FJ. Role of estrogen as initiator of daily LH surges in the ovariectomized rat. Endocrinology (1975) 96(1):50-6. doi:10.1210/ endo-96-1-50

108. Sarkar DK, Chiappa SA, Fink G, Sherwood NM. Gonadotropinreleasing hormone surge in proestrous rats. Nature (1976) 264:461-3. doi:10.1038/264461a0

109. Moenter SM, Caraty A, Locatelli A, Karsch FJ. Pattern of gonadotropinreleasing hormone $(\mathrm{GnRH})$ secretion leading up to ovulation in the ewe: existence of a preovulatory GnRH surge. Endocrinology (1991) 129(3):1175-82. doi:10.1210/endo-129-3-1175

110. Karsch FJ, Bowen JM, Caraty A, Evans NP, Moenter SM. Gonadotropinreleasing hormone requirements for ovulation. Biol Reprod (1997) 56(2):303-9. doi:10.1095/biolreprod56.2.303

111. Wintermantel TM, Campbell RE, Porteous R, Bock D, Grone HJ, Todman MG, et al. Definition of estrogen receptor pathway critical for estrogen positive feedback to gonadotropin-releasing hormone neurons and fertility. Neuron (2006) 52(2):271-80. doi:10.1016/j.neuron.2006.07.023
112. Abraham IM, Herbison AE. Major sex differences in non-genomic estrogen actions on intracellular signaling in mouse brain in vivo. Neuroscience (2005) 131(4):945-51. doi:10.1016/j.neuroscience.2004.10.046

113. Kwakowsky A, Herbison AE, Abraham IM. The role of cAMP response element-binding protein in estrogen negative feedback control of gonadotropin-releasing hormone neurons. J Neurosci (2012) 32(33):11309-17. doi:10.1523/JNEUROSCI.1333-12.2012

114. Mantamadiotis T, Lemberger T, Bleckmann SC, Kern H, Kretz O, Martin Villalba A, et al. Disruption of CREB function in brain leads to neurodegeneration. Nat Genet (2002) 31(1):47-54. doi:10.1038/ng882

115. Skynner MJ, Sim JA, Herbison AE. Detection of estrogen receptor alpha and beta messenger ribonucleic acids in adult gonadotropin-releasing hormone neurons. Endocrinology (1999) 140(11):5195-201. doi:10.1210/ endo.140.11.7146

116. Hrabovszky E, Steinhauser A, Barabas K, Shughrue PJ, Petersen SL, Merchenthaler I, et al. Estrogen receptor-beta immunoreactivity in luteinizing hormone-releasing hormone neurons of the rat brain. Endocrinology (2001) 142(7):3261-4. doi:10.1210/endo.142.7.8176

117. Couse JF, Curtis SW, Washburn TF, Eddy EM, Schomberg DW, Korach KS. Disruption of the mouse oestrogen receptor gene: resulting phenotypes and experimental findings. Biochem Soc Trans (1995) 23(4):929-35. doi:10.1042/ bst0230929

118. Lubahn DB, Moyer JS, Golding TS, Couse JF, Korach KS, Smithies O. Alteration of reproductive function but not prenatal sexual development after insertional disruption of the mouse estrogen receptor gene. Proc Natl Acad Sci U S A (1993) 90(23):11162-6. doi:10.1073/pnas.90.23.11162

119. Christian CA, Moenter SM. Critical roles for fast synaptic transmission in mediating estradiol negative and positive feedback in the neural control of ovulation. Endocrinology (2008) 149(11):5500-8. doi:10.1210/ en.2008-0453

120. Mayer C, Acosta-Martinez M, Dubois SL, Wolfe A, Radovick S, Boehm U, et al. Timing and completion of puberty in female mice depend on estrogen receptor alpha-signaling in kisspeptin neurons. Proc Natl Acad Sci U S A (2010) 107(52):22693-8. doi:10.1073/pnas.1012406108

121. Chappell PE, Schneider JS, Kim P, Xu M, Lydon JP, O’Malley BW, et al. Absence of gonadotropin surges and gonadotropin-releasing hormone self- priming in ovariectomized (OVX), estrogen (E2)-treated, progesterone receptor knockout (PRKO) mice. Endocrinology (1999) 140(8):3653-8. doi:10.1210/endo.140.8.6895

122. Chappell PE, Levine JE. Stimulation of gonadotropin-releasing hormone surges by estrogen. I. Role of hypothalamic progesterone receptors. Endocrinology (2000) 141(4):1477-85. doi:10.1210/endo.141.4.7427

123. Petersen SL, McCrone S, Keller M, Shores S. Effects of estrogen and progesterone on luteinizing hormone-releasing hormone messenger ribonucleic acid levels: consideration of temporal and neuroanatomical variables. Endocrinology (1995) 136(8):3604-10. doi:10.1210/endo.136.8.7628399

124. Krey LC, Tyrey L, Everett JW. The estrogen-induced advance in the cyclic LH surge in the rat: dependency on ovarian progesterone secretion. Endocrinology (1973) 93(2):385-90. doi:10.1210/endo-93-2-385

125. Xia L, Van Vugt D, Alston EJ, Luckhaus J, Ferin M. A surge of gonadotropinreleasing hormone accompanies the estradiol-induced gonadotropin surge in the rhesus monkey. Endocrinology (1992) 131(6):2812-20. doi:10.1210/ endo.131.6.1446619

126. Brom GM, Schwartz NB. Acute changes in the estrous cycle following ovariectomy in the golden hamster. Neuroendocrinology (1968) 3(6):366-77. doi: $10.1159 / 000121725$

127. Ferin M, Tempone A, Zimmering PE, Van de Wiele RL. Effect of antibodies to 17beta-estradiol and progesterone on the estrous cycle of the rat. Endocrinology (1969) 85(6):1070-8. doi:10.1210/endo-85-6-1070

128. Labhsetwar AP. Role of estrogens in ovulation: a study using the estrogenantagonist, I.C.I. 46,474. Endocrinology (1970) 87(3):542-51. doi:10.1210/ endo-87-3-542

129. Herbison AE. Estrogen positive feedback to gonadotropin-releasing hormone $(\mathrm{GnRH})$ neurons in the rodent: the case for the rostral periventricular area of the third ventricle (RP3V). Brain Res Rev (2008) 57(2):277-87. doi:10.1016/j.brainresrev.2007.05.006

130. Smith JT. Sex steroid control of hypothalamic Kiss1 expression in sheep and rodents: comparative aspects. Peptides (2009) 30(1):94-102. doi:10.1016/j. peptides.2008.08.013 
131. Lehman MN, Coolen LM, Goodman RL. Minireview: kisspeptin/neurokinin B/dynorphin (KNDy) cells of the arcuate nucleus: a central node in the control of gonadotropin-releasing hormone secretion. Endocrinology (2010) 151(8):3479-89. doi:10.1210/en.2010-0022

132. Stephens SB, Tolson KP, Rouse ML Jr, Poling MC, Hashimoto-Partyka MK, Mellon PL, et al. Absent progesterone signaling in kisspeptin neurons disrupts the LH surge and impairs fertility in female mice. Endocrinology (2015) 156(9):3091-7. doi:10.1210/en.2015-1300

133. Clarkson J, d'Anglemont de Tassigny X, Colledge WH, Caraty A, Herbison AE. Distribution of kisspeptin neurones in the adult female mouse brain. J Neuroendocrinol (2009) 21(8):673-82. doi:10.1111/j.1365-2826.2009. 01892.x

134. Messager S, Chatzidaki EE, Ma D, Hendrick AG, Zahn D, Dixon J, et al. Kisspeptin directly stimulates gonadotropin-releasing hormone release via $\mathrm{G}$ protein-coupled receptor 54. Proc Natl Acad Sci US A (2005) 102(5):1761-6. doi:10.1073/pnas.0409330102

135. Kirilov M, Clarkson J, Liu X, Roa J, Campos P, Porteous R, et al. Dependence of fertility on kisspeptin-Gpr54 signaling at the GnRH neuron. Nat Commun (2013) 4:2492. doi:10.1038/ncomms3492

136. Novaira HJ, Sonko ML, Hoffman G, Koo Y, Ko C, Wolfe A, et al. Disrupted kisspeptin signaling in $\mathrm{GnRH}$ neurons leads to hypogonadotrophic hypogonadism. Mol Endocrinol (2014) 28(2):225-38. doi:10.1210/me.2013-1319

137. Dror T, Franks J, Kauffman AS. Analysis of multiple positive feedback paradigms demonstrates a complete absence of LH surges and GnRH activation in mice lacking kisspeptin signaling. Biol Reprod (2013) 88(6):146. doi:10.1095/biolreprod.113.108555

138. Han SK, Gottsch ML, Lee KJ, Popa SM, Smith JT, Jakawich SK, et al. Activation of gonadotropin-releasing hormone neurons by kisspeptin as a neuroendocrine switch for the onset of puberty. J Neurosci (2005) 25(49):11349-56. doi:10.1523/JNEUROSCI.3328-05.2005

139. DePaolo LV. Attenuation of preovulatory gonadotrophin surges by epostane: a new inhibitor of 3 beta-hydroxysteroid dehydrogenase. J Endocrinol (1988) 118(1):59-68. doi:10.1677/joe.0.1180059

140. Mahesh VB, Brann DW. Interaction between ovarian and adrenal steroids in the regulation of gonadotropin secretion. J Steroid Biochem Mol Biol (1992) 41(3-8):495-513. doi:10.1016/0960-0760(92)90375-S

141. Hibbert ML, Stouffer RL, Wolf DP, Zelinski-Wooten MB. Midcycle administration of a progesterone synthesis inhibitor prevents ovulation in primates. Proc Natl Acad Sci U S A (1996) 93(5):1897-901. doi:10.1073/ pnas.93.5.1897

142. Remohi J, Balmaceda JP, Rojas FJ, Asch RH. The role of pre-ovulatory progesterone in the midcycle gonadotrophin surge, ovulation and subsequent luteal phase: studies with RU486 in rhesus monkeys. Hum Reprod (1988) 3(4):431-5. doi:10.1093/oxfordjournals.humrep.a136722

143. Gottsch ML, Cunningham MJ, Smith JT, Popa SM, Acohido BV, Crowley WF, et al. A role for kisspeptins in the regulation of gonadotropin secretion in the mouse. Endocrinology (2004) 145(9):4073-7. doi:10.1210/en.2004-0431

144. Irwig MS, Fraley GS, Smith JT, Acohido BV, Popa SM, Cunningham MJ, et al. Kisspeptin activation of gonadotropin releasing hormone neurons and regulation of KiSS-1 mRNA in the male rat. Neuroendocrinology (2004) 80(4):264-72. doi:10.1159/000083140

145. Thompson EL, Patterson M, Murphy KG, Smith KL, Dhillo WS, Todd JF, et al. Central and peripheral administration of kisspeptin-10 stimulates the hypothalamic-pituitary-gonadal axis. J Neuroendocrinol (2004) 16:850-8. doi:10.1111/j.1365-2826.2004.01240.x

146. Quadros PS, Pfau JL, Wagner CK. Distribution of progesterone receptor immunoreactivity in the fetal and neonatal rat forebrain. J Comp Neurol (2007) 504(1):42-56. doi:10.1002/cne.21427

147. Clarkson J, d'Anglemont de Tassigny X, Moreno AS, Colledge WH, Herbison AE. Kisspeptin-GPR54 signaling is essential for preovulatory gonadotropinreleasing hormone neuron activation and the luteinizing hormone surge. J Neurosci (2008) 28(35):8691-7. doi:10.1523/JNEUROSCI.1775-08.2008

148. Gal A, Lin PC, Cacioppo JA, Hannon PR, Mahoney MM, Wolfe A, et al. Loss of fertility in the absence of progesterone receptor expression in kisspeptin neurons of female mice. PLoS One (2016) 11(7):e0159534. doi:10.1371/ journal.pone.0159534

149. Mittelman-Smith MA, Williams H, Krajewski-Hall SJ, Lai J, Ciofi P, McMullen NT, et al. Arcuate kisspeptin/neurokinin B/dynorphin (KNDy) neurons mediate the estrogen suppression of gonadotropin secretion and body weight. Endocrinology (2012) 153(6):2800-12. doi:10.1210/ en.2012-1045

150. Smith JT. Sex steroid regulation of kisspeptin circuits. Adv Exp Med Biol (2013) 784:275-95. doi:10.1007/978-1-4614-6199-9_13

Conflict of Interest Statement: The authors declare that the research was conducted in the absence of any commercial or financial relationships that could be construed as a potential conflict of interest.

Copyright (c) 2017 Mittelman-Smith, Rudolph, Mohr and Micevych. This is an open-access article distributed under the terms of the Creative Commons Attribution License (CC BY). The use, distribution or reproduction in other forums is permitted, provided the original author(s) or licensor are credited and that the original publication in this journal is cited, in accordance with accepted academic practice. No use, distribution or reproduction is permitted which does not comply with these terms. 